\title{
Labyrinthe
}

$11 \mid 2002$

Numéro 11

\section{L'abbaye cistercienne de Silvanès au XIIe siècle, entre gestion et "gesta"}

\section{Aude-Marie Doucet}

\section{(2) OpenEdition \\ 12 Journals}

\section{Electronic version}

URL: http://journals.openedition.org/labyrinthe/664

DOI: $10.4000 /$ labyrinthe.664

ISSN: 1950-6031

\section{Publisher}

Hermann

\section{Printed version}

Date of publication: 14 January 2002

Number of pages: 119-122

\section{Electronic reference}

Aude-Marie Doucet, "L'abbaye cistercienne de Silvanès au XIle siècle, entre gestion et "gesta" », Labyrinthe [Online], 11 | 2002, Online since 15 April 2005, connection on 21 April 2019. URL : http:// journals.openedition.org/labyrinthe/664; DOI : 10.4000/labyrinthe.664

This text was automatically generated on 21 April 2019

Propriété intellectuelle 


\title{
L'abbaye cistercienne de Silvanès au XIIe siècle, entre gestion et "gesta"
}

\author{
Aude-Marie Doucet
}

